\title{
FRAUDULENT FINANCIAL STATEMENT Evidence from Statement on Auditing Standard No. 99*
}

\section{Suyanto**}

The goals of this study are to empirically identify fraud risk factors and construct a model to predict the likelihood of financial statement frauds based on SAS No. 99. Employing logistic regression on 143 firms, this research finds that fraud risk factor proxies for Pressure — net profit/total assets — and Opportunity — inventory/ total assets ratio, related party transactions, and Big 4-are significantly associated with fraudulent financial statements, whereas none of the fraud risk factor proxies for Rationalization is significantly associated with fraudulent financial statements. Consistent with prior research, it seems that the likelihood of fraudulent financial statements is easier to be observed publicly using fraud risk factor proxies for Pressure and Opportunity rather than Rationalization. The constructed model can correctly classify firms with a relatively high success rate.

Keywords: financial statement frauds; fraud triangle; fraud risk factors; SAS 99

* Data for this paper come from public sources.

** I would like to thank Dr. Ken Yaotsung Chen for his comments and critiques on this article. I also give appreciation to Camilo Osuna and Regi Muzio Ponziani, my outside readers, for their comments. 
Gadjah Mada International Journal of Business, January -April 2009, Vol. 11, No. 1

\section{Introduction}

In the beginning of the $21^{\text {st }}$ century, business world was upset by a series of corporate financial and accounting scandals; Enron, WorldCom, and Xerox are just a few companies that daunted public trust and dissipated tremendous dollars of market capitalization. Five companies-Enron, WorldCom, Qwest, Tyco, and Global Crossing- and their respective losses on their market capitalization caused by accounting scandals accounted to approximately $\$ 460$ billion (Cotton 2002). Enron's loss itself totaled around $\$ 70$ billion (Rezaee 2005). A financial fraud assessment survey conducted by KPMG (2003) finds that 70 percent of the responding companies have experienced at least one type of fraud, increasing by 13 percent compared to the results obtained with the same survey in 1998.

These and other series of financial frauds and accounting scandals seemingly fostered AICPA to issue the Statement on Auditing Standards (SAS) No. 99, "Consideration of Fraud in a Financial Statement Audit", in October 2002, which superseded SAS No. 53 (1988) and SAS No. 82 (1997). SAS No. 99 consists of an extensive list of fraud risk indicators. The Standard advocates for auditors to be more cautious in the audit process.

This research intends to identify fraud risk factors stated in SAS No. 99 (AICPA 2002) -perceived Pressure/ Incentive, Opportunity, and Attitude/ Rationalization- and empirically re- lates those factors to the impending likelihood of financial statement fraud. This study also aims to construct a fraud prediction model to predict the likelihood of financial statement fraud based on the identified fraud risk factors. Financial statement fraud usually involves management because managers can directly or indirectly manipulate accounting records and present fraudulent financial information by overriding controls or directing employees to carry out the fraud. Even though it is difficult to discover fraud (Albrecht et al. 2006), fraudulent activities can still be predicted by considering certain conditions.

Using sample data mainly from Audit Analytics for financial restatement database, SEC EDGAR for governance mechanism information, and COMPUSTAT database for financial information, this study makes use of several variables present for fraudulent firms and possibly absent for nonfraudulent firms, and empirically tests them in order to identify and detect fraud risk factors and relates them to the likelihood of financial statement frauds. Firstly, a sample was selected from the Audit Non-Reliable (Restatement) of Audit Analytics to obtain firms engaged in fraudulent financial statement activities (financial fraud, irregularities, and misrepresentation). Secondly, data on governance mechanisms from SEC's EDGAR and financial information from COMPUSTAT database were used as accompanying attributes of fraudulent and non-fraudulent firms sample. 
This research finds that a Pressure proxy variable-net profit/total assetsand Opportunity proxy variables -inventory/total assets, related party transaction (RPTRANS) and Big 4/5 audit firms (BIG4)-are significantly related to the tendency of committing fraud, whereas Rationalization proxy variables are insignificantly related to the likelihood of fraudulent financial statement. Rationalization of fraud is apparently the most difficult factor among other fraud triangle elements to be observed by public data. Furthermore, the findings include the construction of a fraud prediction model, which accurately predicts fraud with a success rate up to 67.1 percent. By using cross validation method, this model can correctly classify non-fraudulent firms by 77 percent and fraudulent firms by 51 percent.

\section{Theory and Hypotheses Development}

Fraud detection has become a critical concern of researchers and academics, and this leads them to conduct a myriad of empirical research. Fraud triangle -Pressure, Opportunity, and Rationalization- is a well recognized technique used to examine fraud occurrences. The fraud triangle was widely introduced by Cressey in 1953 after conducting research on inmates who had been alleged of violation of financial trust. Cressey (1953) argues that a fraud triangle is always present when a fraud occurs. AICPA (2002) has adopted this theory and further proposes it in SAS No. 99. Based on the proposal, AICPA (2002) claims that only one fraud risk factor needs to be present for the occurrence of fraud.

AICPA (2002) defines fraud in SAS No. 99 as an intentional act that results in a material misstatement in financial statements, which are the subject of the audit. The Standard recognizes two types of misstatements pertaining to auditor's consideration of fraud: (1) misstatement arising from fraudulent financial reporting and (2) misstatement arising from misappropriation of assets. This study is specifically focused on fraudulent financial reporting. SAS No. 99 (AICPA 2002) defines fraudulent financial reporting as intentional misstatements or omissions of monetary amounts or disclosures in financial statements designed to deceive financial statement users, disregarding critical financial information and violating the conformity to the generally accepted accounting principles (GAAP). Financial statement fraud generally involves intention and deception by knowledgeable people (e.g., top executives, auditors) with a set of well-planned schemes and a considerable gamesmanship (Rezaee 2005).

Three conditions depicted in SAS No. 99 are present in fraudulent behaviors:

1. Pressure. Pressure constitutes an incentive to act in a given manner. Likewise, being under pressure increases the probability of committing fraud; for instances: financial needs, needs for providing better 
results than actual performance, frustration with work, or even a challenge to manipulate the system. Albrecht et al. (2006) state that fraud can be perpetrated to benefit oneself or to benefit an organization. They provide four types of Pressure examples: (1) financial pressure, (2) vice, (3) work-related pressure, and (4) other pressure.

2. Opportunity. Opportunity is defined as existing circumstances -such as the absence of controls, ineffective controls, or the ability of management to override controls- that provides an opportunity for fraud to be perpetrated. Albrecht et al. (2006) argue that Opportunity is perceived as concealing or avoiding punishments. They also note six major factors that increase opportunities for an individual to commit frauds within an organization: (1) lack of or circumvention of controls purported to prevent or detect fraudulent behaviors, (2) inability to judge quality of performance, (3) failure to discipline fraud perpetrators, (4) lack of access to information, (5) ignorance, apathy, and incapacity, and (6) lack of a fraud audit.

3. Rationalization (Attitude). Those involved in financial statement fraud are able to rationalize fraudulent acts as being consistent with their personal code of ethics. Some individuals possess attitudes, characters or set of ethical values that allow them to knowingly and intentionally commit dishonest acts.
This research develops hypotheses derived from the fraud triangle above as introduced by SAS No. 99. Therefore, this study empirically hypothesizes that the fraud risk factors categorized by Pressure, Opportunity, and Rationalization- are associated with the higher likelihood of fraudulent financial reporting.

FRAUD = f (Pressure, Opportunity, Rationalization)

Each fraud risk factor will be proxied by associated variables. Hence, the variables used in this research are as follows:

\section{Pressure Variables}

Albrecht et al. (2006) state that financial ratios can be a useful tool for detecting fraudulent financial reporting. Financial ratio is one of the analytical procedures, as SAS No. 99 suggests, derived from an entity's financial and operational data to help auditor identify fraud (Kaminski et al. 2004). Unusual changes in financial ratios may indicate fraudulent activities carried out by managers. Some of the financial ratios utilized by this research are: financial leverage, capital turnover, and profitability, which serve as proxies for Pressure. This research predicts that these financial ratios are associated with fraudulent financial reporting.
1. Financial Leverage - Total Liabil- ity/Total Assets (LEV). Financial distress may be an incentive factor for management to commit fraud 
(Loebbecke et al.1989; Stice 1991; Kirkos et al. 2007). In this study, total liability/total assets or financial leverage (LEV) is used as a proxy for Pressure. Persons (1995) suggests that there is an association between higher leverage and higher likelihood of loan agreement violation, and also an association between higher leverage and less ability to obtain additional funding through borrowing. Furthermore, management typically tends to manipulate financial statements to cope with the requirement for covenants (Kirkos et al. 2007). Thus, this investigation expects to observe a positive and statistically significant link between financial distress and the likelihood of fraudulent financial statements.

H1a: Firms with higher financial leverage will be more likely to engage in financial statement frauds.

2. Capital Turnover-Sales/Total Assets (SALTA). Capital turnover measures the sales generating power of a firm's assets and also management ability to deal with competitive situations (Pearsons 1995). He argues that fraudulent firm management may be less competitive than that of non-fraudulent firms in using the firm's assets to generate sales. If a firm is not able to successfully compete, it may be fostered to produce fraudulent financial statements (Persons 1995). Therefore, this study expects to see an association between capital turn- over and fraudulent financial statements.

H1b: Firms with lower net sales/ total assets ratio will be more likely to engage in financial statement frauds.

3. Profitability - Net Profit/Total Assets (NPROFTA). Persons (1995) states that firms with lower profitability are likely to overstate revenues or underestimate expenses. Kreutzfeldt and Wallace (1986) and Persons (1995) find that firms with lower profitability are significantly linked to have more errors in their financial statements than firms with higher profitability. This research uses net profit/total assets (NPROFTA), and expects that NPROFTA is significantly associated with fraudulent financial statements.

H1c: Firms with lower net profits/ total assets ratio will be more likely to engage in financial statement frauds.

\section{Opportunity Variables}

Opportunity, in this study, consists of related party transaction, Big 4 , and inventory/total assets ratio.

1. Related Party Transaction (RPTRANS). SAS No. 99 suggests that auditors should consider related party transaction to be one of the fraud risk factors since it provides opportunities to engage in fraudulent financial reporting. Related party transaction is defined as a transaction done between a com- 
pany and an insider - in the form of a subsidiary, family-related company, employee, and so forth. This kind of transaction may not reflect arm's — length bargaining, which is a crucial point for revenue recognition between independent parties. Carmichael (1999) states if a transaction materially differs from its economic substance, profit recognition should generally be deferred. Related party transaction, unfortunately, for many cases is allegedly used to manipulate earnings, loot companies, and commit frauds (Young 2005). Young (2005) also asserts that recent frauds in Enron, Tyco, Adelphia, WorldCom, and Holingger typically involved related party transactions. Chen and Elder (2007) consistently find that firms with more related party transactions tend to engage in fraud. Therefore, this study expects to observe a positive relationship between related party transactions and the likelihood of financial statement frauds.

H2a: Firms involved related party transactions will be more likely to engage in financial statement frauds.

2. Big 4 (BIG4). Prior studies find an association between audit-firm quality and Big 4 (audit-firm size). Big 4 represents the four largest international accounting firms (Deloitte \& Touche, Ernst and Young, KPMG, and Pricewaterhouse Coopers). Palmrose (1988) finds that Big 8 has higher audit quality shown by low litigation activities than does Non-Big 8. Audit-firm quality is proxied by audit-firm size, brand name, and its ability to mitigate agency problems (DeFond 1992). Farber (2005) consistently shows that fraudulent firms have fewer instances of employing Big 4 audit firms. These findings indicate that Big 4 audit-firm size provides better audit-firm quality than does Non-Big 4, and reduces a firm's opportunity to engage in frauds. Therefore, this study predicts that fraudulent firms are more likely to have a lower probability of employing a Big 4 audit firm.

H2b: Firms audited by a Big 4 audit firm will be less likely to engage in fraudulent financial reporting.

3. Inventory/Total Assets (INVTA). Inventory is one of the easiest accounts to manipulate (Stice 1991; Person 1995), since inventories involve a subjective estimation that makes it more difficult to be audited. Therefore, it is prone to fraudulent falsification (Kirkos et al. 2007). Inventory fraud typically exerts some methods such as reporting inventories at a lower cost and recording obsolete inventories (Kirkos et al. 2007). Persons (1995) finds that fraudulent firms tend to have higher inventory/total assets (INVTA) than do non-fraudulent firms. This study uses inventory/ total assets (INVTA) as one of the Pressure proxies, and expects INVTA to have a positive associa- 
Suyanto-Fraudulent Financial Statement

tion with fraudulent financial statements.

H2c: Firms with higher inventory/ total assets ratio will be more likely to engage in financial statement frauds.

\section{Rationalization Variables}

Skousen and Wright (2006) argue that even though Rationalization is a necessary factor in the fraud triangle, it is still very difficult to observe an individual's rationale. Furthermore, they do not find any significant fraud risk factors as proxies for Rationalization. Ramos (2003) states that auditors cannot possibly know with certainty what a person's ethical standards and beliefs are. Even more, Brazel et al. (2007) do not include any fraud risk factors as proxies for Rationalization in their empirical research. They state that it is very limited or even unavailable public data to be surrogates for management rationales or attitudes. On the other hand, Ramos (2003) notes that auditors may become aware of circumstances that indicate the possible presence of an attitude that potentially induces fraud risk. Chen and Elder (2007) find some significant fraud risk factors, such as the number of earnings restatement, the number of internal auditor switches, and the number of internal auditor switches, as proxies for Rationalization or Attitude. In addition, audit qualifications are perceived to have a negative effect on a firm's stock price (Chow and Rice 1982) and its ability to borrow funds (Schwartz and Menon 1985). Accord- ingly, a firm with a qualified opinion may change to other auditors. This fact is exemplified by research conducted by Johnson and Lys (1990) and Krishnan, Krishnan, and Stephens (1996) which find that firms tend to change auditors after receiving a qualified opinion. Following Chen and Elder (2007), Johnson and Lys (1990), and Krishnan, Krishnan, and Stephens (1996), this study involves auditor change(AUDCHANG) and auditopinion (AO) as proxies for Rationalization. These variables will be accompanied by the going concern report (GC) variable, which is expected to be a suitable parameter for Rationalization.

1. Auditor Change (CPA). Management is more likely to switch its auditors in anticipation of some agency conflicts (DeFond 1992). Schewartz and Menon (1985) theorize about failing firms having a greater tendency to switch auditors than do healthier firms. Furthermore, they argue that failing firms that change their auditors have preferences to switch to a different class of CPA firms. However, they also note that the size of the auditing firm does not have a considerable implication. Chen and Elder (2007) state that firms with more frequent audit switches are more likely to engage in financial reporting frauds. Therefore, this study follows this hypothesis accordingly, and expects a positive association between auditor switching and fraudulent financial statements. 
Gadjah Mada International Journal of Business, January -April 2009, Vol. 11, No. 1

H3a: Firms with more often auditor switches have a tendency to engage in fraudulent reporting.

2. Audit Opinion (AO). Vermeer (2003) reveals that SAS No. 82 has not changed an auditor's tolerance toward a client's attempts to manage earnings. He even finds that auditors have become more tolerant with a client's attempts to manage earnings over time. Earnings management is management decision-making process that opens roads to incentives or insight management, terms that might lead to the Rationalization of fraudulent financial reporting (Beneish 1997; Francis and Krishnan 1999; Vermeer 2003; and Skousen and Wright 2006). Following Skousen and Wright (2006), this research uses Audit Opinion as one of the proxies for Rationalization. Thus, this study predicts that firms committing earnings management will tend to rationalize its fraudulent financial reporting.

H3b: Firms that get an unqualified opinion with an additional explanatory language will be more likely to engage in fraudulent financial reporting.

3. Going Concern (GC). Statement on Auditing Standard (SAS) No. 59, The Auditor's Consideration of Entity's Ability to Continue As a Going Concern, requires auditors to assess the client's ability to con- tinue as a going concern and assess management plans and provide guidance as to what information and steps to consider if auditors believe that any substantial going concerns are present. Furthermore, the Standard considers the adequacy of financial statement disclosure as a sign of the ability to continue as a going concern. Ellingsen et al. (1989) define going concern as management ability to continue operations. They note that going concern can be affected by many causes, such as foreign competition, declining commodity prices, and poor management. Hopwood et al. (1994) argue that the examination of an auditor's going-concern decision should be tested using stressed and non-stressed samples, because bankrupt firms have potentials to engage in fraudulent financial reporting. Thus, in this research, it is expected that firms with the presence of going concerns are positively associated with fraudulent financial reporting.

H3c: Firms with an auditor's going-concern opinion tend to engage in financial statement frauds.

\section{Sample Selection and Description}

Sample used to examine the hypotheses consists of 143 publicly traded firms; 55 of which are fraudulent firms and 88 non-fraudulent firms. 
Suyanto-Fraudulent Financial Statement

\section{Fraudulent Firm Selection}

This research utilizes data from three different sources. Initial sample is retrieved from Audit Analytics, which provides restatement data of firms engaged in financial fraudulent activities. These firms were allegedly involved in fraudulent financial statements between 2001 and 2006. This study looks at 90 firms identified as having been engaged in financial statement frauds occurring during this period. Fraudulent firms are defined as firms obliged to do restatements because of financial frauds, irregularities, and misrepresentations. This study subsequently collects governance mechanism data from EDGAR SEC
Filling and Report and financial statement data from COMPUSTAT database for the corresponding year of the alleged fraud. Eliminating financial institutions (bank, insurance, etc.) and missing or incomplete data, the sample comprises 55 fraudulent firms, representing 28 different industries. Financial institutions are excluded from this sample because they lack certain financial information such as accounts receivable and inventories (Persons 1995).

Table 1, Panel A shows fraudulent firm sample selection and its distribution in the period of 2001-2006, while Panel B presents industry representation of fraudulent firms.

Table 1. Sample Selection Method

\section{Panel A: Fraudulent Firm Selection}

Initial fraudulent firm sample 2001 - 2006

Less:

- Incomplete financial data

- Incomplete governance data

- Financial Institutions
90

19

12

4

Total

55

Fraud Occurrence
\begin{tabular}{rllr}
2001 & 8 & 2004 & 7 \\
2002 & 8 & 2005 & 17 \\
2003 & 9 & 2006 & 6 \\
\hline & & & 55
\end{tabular}


Gadjah Mada International Journal of Business, January -April 2009, Vol. 11, No. 1

\section{Continued from Table 1}

\section{Panel B: Industry Representation of Fraudulent Firms}

\begin{tabular}{|c|c|c|c|}
\hline SIC Code & Industry & Number & Percent \\
\hline 10 & Metal Mining & 1 & $1.82 \%$ \\
\hline 12 & Bituminous Coal and Lignite Surface Mining & 1 & $1.82 \%$ \\
\hline 13 & Drilling Oil and Gas Wells & 2 & $3.64 \%$ \\
\hline 14 & Mining \& Quarrying of Nonmetallic Minerals (No Fuels) & 1 & $1.82 \%$ \\
\hline 16 & Heavy Construction Other Than Building Construction & 1 & $1.82 \%$ \\
\hline 22 & Textile Mill Products & 1 & $1.82 \%$ \\
\hline 23 & Apparel \& Other Finished Products & 3 & $5.45 \%$ \\
\hline 28 & Chemical and Allied Products & 3 & $5.45 \%$ \\
\hline 33 & Iron and Steel Foundries & 1 & $1.82 \%$ \\
\hline 34 & Fabricated Metal Products & 1 & $1.82 \%$ \\
\hline 35 & Industrial and Commercial Machinery and Computer Equipment & 1 & $1.82 \%$ \\
\hline 36 & Electronic and Other Electrical Equipment and Components & 4 & $7.27 \%$ \\
\hline 37 & Motor Vehicle Parts and Accessories & 1 & $1.82 \%$ \\
\hline 38 & Measuring, Analyzing, and Controlling Instruments & 1 & $1.82 \%$ \\
\hline 42 & Trucking & 1 & $1.82 \%$ \\
\hline 45 & Air Transportation & 1 & $1.82 \%$ \\
\hline 47 & Arrangement of Transportation of Freight and Cargo & 1 & $1.82 \%$ \\
\hline 48 & Communications & 1 & $1.82 \%$ \\
\hline 49 & Electric, Gas, and Sanitary Services & 2 & $3.64 \%$ \\
\hline 50 & Wholesale Trade - Durable Goods & 1 & $1.82 \%$ \\
\hline 51 & Wholesale Trade - Non Durable Goods & 3 & $5.45 \%$ \\
\hline 67 & Holding and Other Investment Offices & 1 & $1.82 \%$ \\
\hline 73 & Business Services & 13 & $23.64 \%$ \\
\hline 75 & Services-Automotive Repair, Services \& Parking & 1 & $1.82 \%$ \\
\hline 78 & Motion Picture and Video Tape Production and Distribution & 2 & $3.64 \%$ \\
\hline 80 & Health Services & 3 & $5.45 \%$ \\
\hline 83 & Services-Social Services & 1 & $1.82 \%$ \\
\hline 87 & Management Consulting Services & 2 & $3.64 \%$ \\
\hline Total & & 55 & $100.00 \%$ \\
\hline
\end{tabular}


Suyanto-Fraudulent Financial Statement

\section{Comparing Fraudulent Firms to Non-Fraudulent Firms}

Following Beasley (1996), and Bell and Carcello (2000), this study uses a control group, the non-fraudulent firms, in terms of year, industry, and firm size. Matching fraudulent and non-fraudulent firms is subject to similar:

1. Year. This research identifies nonfraudulent firms in the same period of fraud occurrence from 2001 to 2006.

2. Industry. Firms in the same industry are expected to have similar business environments and accounting and reporting requirements (St. Pierre and Anderson 1984; Persons 1995). The study selects matched non-fraudulent firms based on the same four-digit SIC code (industry membership) as that of the fraudulent firms. If there is no similar four-digit SIC code identified, three-digit SIC code matching is used. If there is no similar three-digit SIC code identified, correspondingly, a two-digit SIC code matching is performed.

3. Firm Size. If non-fraudulent firms identified in steps 1 and 2 are more than five firms, they will be reduced to five firms whose net sales are in the range of $+/-30$ percent of the fraudulent firms' net sales. According to Kaminski et al. (2004), if the non-fraudulent firms' net sales are beyond the range of $+/-30$ percent, then their total asets will be compared to fraudulent firms' total assets. It is expected that the nonfraudulent firms' total assets will be in the range of $+/$ - 30 percent of fraudulent firms' total assets. This study chooses five matched nonfraudulent firms for each fraudulent firm. Exception prevails if the

Table 2. Descriptive Statistics

\begin{tabular}{llrrr}
\hline & & $\begin{array}{c}\text { Fraudulent } \\
\text { Firms }\end{array}$ & & $\begin{array}{c}\text { No-Fraudulent } \\
\text { Firms }\end{array}$ \\
Net Sales & Mean & $1,055.657$ & & 671.509 \\
& Median & 168.861 & & 126.479 \\
& Standard Deviation & $7,199.252$ & & $1,531.789$ \\
& Maximum & $9,157.660$ & & $8,733.947$ \\
& Minimum & 1.144 & & 0.128 \\
& Mean & & & \\
& Median & 342.586 & & 156.020 \\
& Standard Deviation & $3,070.993$ & & 197.298 \\
& Maximum & $11,945.200$ & & 543.338 \\
& Minimum & 36.800 & & 26.070 \\
\hline
\end{tabular}


Gadjah Mada International Journal of Business, January -April 2009, Vol. 11, No. 1

matched non-fraudulent firms in the same industry total less than five firms. Since this study does not find a complete dataset using a single criterion (net sales), an additional criterion (total assets) is necessary to match fraudulent firms and non-fraudulent firms, which consequently may disrupt the matching process.

Table 2 shows descriptive statistics of fraudulent and non-fraudulent firms. The table indicates that the fraudulent firms and non-fraudulent firms do not differ significantly based on net sales and total assets.

\section{Research Design}

Since the dependent variable, FRAUD, is dichotomous, the study uses a logistic regression model to test the hypothesis of association between fraud risk factors and the likelihood of fraudulent financial reporting. The regression is based on a matched-pair sample in which 38.5 percent of the firms have committed fraudulent financial statements and the rest have not committed fraudulent financial statements.

$$
\begin{aligned}
\text { FRAUD }= & \beta_{0}+\beta_{1} \text { LEV }+\beta_{2} \text { SALTA }+ \\
& \beta_{3} \text { NPROFTA }+\beta_{4} \text { INVTA }+ \\
& \beta_{5} \text { RPTRANS }+\beta_{6} \text { BIG }+ \\
& \beta_{7} \text { CPA }+\beta_{8} \mathrm{GC}+ \\
& \beta_{9} \mathrm{AO}+\beta_{10} \text { LnASSETS }+\varepsilon
\end{aligned}
$$

where,

FRAUD = a dummy variable with a value of 1 if a firm is alleged to have committed a financial statement fraud, and a value of 0 otherwise.

LEV = ratio of Total Debt/Total Assets.

SALTA = ratio of Sales/Total Assets.

NPROFTA $=$ ratio of Net Profits/Total Assets.

INVTA = ratio of Inventory/Total Assets.

RPTRANS $=$ a dummy variable with a value of 1 if a firm is engaged in related party transactions and a value of 0 otherwise.

BIG4 = a dummy variable with a value of 1 if a firm is audited by a Big 4 accounting firm and a value of 0 otherwise.

CPA = a dummy variable with a value of 1 if a firm switches its auditor and a value of 0 otherwise.

GC = a dummy variable with a value of 1 if a goingconcern opinion is issued by auditor and a value of 0 otherwise.

AO = a dummy variable with a value of 1 if a firm has an unqualified auditor and a value of 0 otherwise.

LnASSETS $=$ Ln Total Assets.

$\varepsilon \quad=$ the residual.

In this research, FRAUD, the dependent variable, is a dummy variable 
with a value of 1 (one) if a firm is engaged in fraudulent financial statement and a value of 0 (zero) otherwise. Hypothesis 1 states that the fraud risk factors for Pressure are positively associated with the likelihood of fraudulent financial statements. More specifically, the study hypothesizes that total debt/total assets ratio (LEV), sales/total assets ratio (SALTA), and net profits/total assets ratio (NPROFTA), are related to the likelihood of fraudulent financial statements.

Hypothesis 2 (H2) proposes that fraud risk factors for Opportunity are related to the engagement in fraudulent financial statements. In this case, this research hypothesizes that inventory/total assets ratio (INVTA), related party transactions (RPTRANS), and Big 4 or 5 (BIG4), are associated with the likelihood of financial statement frauds.

Hypothesis 3(H3) states that fraud risk factors for Rationalization are related to the increasing tendency to engage in fraudulent financial statements. This study expects auditor change (CPA), audit opinion (AO), and going-concern opinion (GC) to be associated with the likelihood of financial statement frauds. Following Chen and Elder (2007), this research uses firm size (ASSETS) as a control variable, and expects that assets is negatively associated with the likelihood of fraudulent financial statements since firms with bigger assets (firm size) tend to have stronger internal controls than do smaller firms (Beasley et al. 1999).

Following Chen and Elder(2007), this research initially tests individual hypotheses for each fraud risk factor proxy, and then simultaneously uses full regression for all three fraud risk factor proxies. This study also includes ASSETS as a control variable for both individual fraud risk factor proxy and the full regression model.

\section{Empirical Results and Additional Analysis}

The independent variables of this study are selected by performing an initial assessment of 30 variables, which at length result in the use of 11 independent variables. Following Chen and Elder (2007), this study selects three independent variables for each fraud risk factor based on statistical criteria from the univariate analysis as shown in Tables 3 and 4. Table 3 shows the t-test and Wilcoxon SignRank test. The correlations among dependent variable and independent variables are reported in Table 4.

In selecting independent variables, this study also uses an initial assessment using all explanatory variables in logistic regression model as in Table 5. In this step, some variables derived from other subsequent variables are omitted to avoid the consequences of collinearity. The assessment finds that these three variables, INVTA, RPTRANS and BIG4 representing proxies for Opportunity, are statistically significant. 
Gadjah Mada International Journal of Business, January -April 2009, Vol. 11, No. 1

Table 3. T-tests and Wilcoxon Sign-Rank Test

\begin{tabular}{|c|c|c|c|c|c|c|c|c|}
\hline \multirow[t]{2}{*}{ Variable } & \multicolumn{3}{|c|}{ Fraudulent Firms } & \multicolumn{3}{|c|}{ NFraudulent Firms } & \multicolumn{2}{|c|}{ Wilcoxon Test } \\
\hline & Means & Median & SD & Means & Median & SD & $\mathrm{Z}$ & $\mathbf{P}$ \\
\hline NCFO & 0.3091 & 0.0000 & 0.4664 & 0.3182 & 0.0000 & 0.4684 & -0.1135 & 0.9096 \\
\hline LEV & 0.5683 & 0.5783 & 0.2819 & 0.5060 & 0.4600 & 0.2746 & -1.2822 & 0.1998 \\
\hline ROA & -0.1326 & -0.0162 & 0.3412 & -0.0636 & 0.0081 & 0.2525 & -1.3320 & 0.1829 \\
\hline SALAR & 9.2133 & 5.6482 & 13.6410 & 17.4856 & 6.2430 & 69.3699 & -0.5270 & 0.5982 \\
\hline SALTA & 1.2231 & 1.0190 & 0.9968 & 1.1852 & 0.7189 & 1.3767 & -1.2822 & 0.1998 \\
\hline NPROFTA & -0.1336 & -0.0162 & 0.3404 & -0.0643 & 0.0075 & 0.2527 & -1.3486 & 0.1775 \\
\hline WCAPTA & 0.2084 & 0.2014 & 0.2364 & 0.2086 & 0.2244 & 0.2563 & -0.2677 & 0.7890 \\
\hline EBIT & 392.4733 & 23.4440 & 1937.9645 & 92.2728 & 8.8015 & 216.7345 & -1.3859 & 0.1658 \\
\hline DETEQ & 0.5010 & 0.9540 & 21.6992 & 2.2794 & 0.6888 & 6.0173 & -0.8714 & 0.3835 \\
\hline INVSAL & 0.0811 & 0.0316 & 0.1077 & 0.0638 & 0.0068 & 0.0991 & -1.2692 & 0.2044 \\
\hline INVTA & 0.0876 & 0.0317 & 0.1156 & 0.0565 & 0.0116 & 0.0883 & -1.5120 & 0.1305 \\
\hline DUALITY & 0.6182 & 1.0000 & 0.4903 & 0.6023 & 1.0000 & 0.4922 & -0.1890 & 0.8501 \\
\hline BODMEET & 10.4909 & 9.0000 & 7.0261 & 9.0000 & 8.0000 & 4.6929 & -0.8205 & 0.4119 \\
\hline BODSIZ & 7.7818 & 8.0000 & 2.1662 & 7.4545 & 7.0000 & 1.9529 & -0.7788 & 0.4361 \\
\hline INSBOD & 1.7636 & 1.0000 & 0.9806 & 1.8409 & 2.0000 & 1.0382 & -0.4765 & 0.6337 \\
\hline OUTB & 6.0182 & 6.0000 & 2.1559 & 5.6023 & 5.5000 & 1.8291 & -0.8857 & 0.3758 \\
\hline ACMEET & 11.7091 & 9.0000 & 7.7212 & 9.7727 & 9.0000 & 6.0281 & -1.2199 & 0.2225 \\
\hline ACSIZ & 3.4909 & 3.0000 & 0.8136 & 3.3182 & 3.0000 & 0.9890 & -0.6215 & 0.5343 \\
\hline OUTAC & 3.4727 & 3.0000 & 0.8357 & 3.2841 & 3.0000 & 1.0278 & -0.6550 & 0.5125 \\
\hline ACCEXP & 0.9818 & 1.0000 & 0.7069 & 0.9545 & 1.0000 & 0.9086 & -0.5578 & 0.5770 \\
\hline FINEXP & 2.1636 & 2.0000 & 1.0321 & 1.9432 & 2.0000 & 1.2627 & -1.2943 & 0.1956 \\
\hline NONBEXP & 0.3273 & 0.0000 & 0.5112 & 0.4205 & 0.0000 & 0.6200 & -0.7028 & 0.4822 \\
\hline RPTRANS & 0.4545 & 0.0000 & 0.5025 & 0.1023 & 0.0000 & 0.3047 & -4.7973 & 0.0000 \\
\hline BIG4 & 0.9273 & 1.0000 & 0.2621 & 0.7273 & 1.0000 & 0.4479 & -2.9219 & 0.0035 \\
\hline СРA & 0.2909 & 0.0000 & 0.4584 & 0.4318 & 0.0000 & 0.4982 & -1.6851 & 0.0920 \\
\hline GC & 0.0727 & 0.0000 & 0.2621 & 0.0682 & 0.0000 & 0.2535 & -0.1033 & 0.9177 \\
\hline $\mathrm{AO}$ & 0.9818 & 1.0000 & 0.1348 & 0.9886 & 1.0000 & 0.1066 & -0.3366 & 0.7364 \\
\hline ICD & 0.7091 & 1.0000 & 0.4584 & 0.7841 & 1.0000 & 0.4138 & -1.0113 & 0.3119 \\
\hline ICA & 0.5455 & 1.0000 & 0.5025 & 0.6705 & 1.0000 & 0.4727 & -1.4948 & 0.1350 \\
\hline FRAUD & $\begin{array}{c}\text { = a dummy var } \\
\text { and a value }\end{array}$ & f 0 otherwi & $\begin{array}{l}\text { value of } 1 \text { if a } \\
\text { ise. }\end{array}$ & c.. & itonav & . & lancial stat & ment fraud \\
\hline NCFO & $\begin{array}{l}\text { = a dummy va } \\
\text { otherwise. }\end{array}$ & iable with & a value of $1 \mathrm{i}$ & f a firm he & legative 0 & erating cas & flows and & value of 0 \\
\hline LEV & $=$ ratio of Tota & Debt/Total & lassets. & & & & & \\
\hline ROA & $=$ ratio of Retu & $\mathrm{m} /$ Total As & ssets. & & & & & \\
\hline
\end{tabular}

130 
Suyanto-Fraudulent Financial Statement

\section{Continued from Table 3}

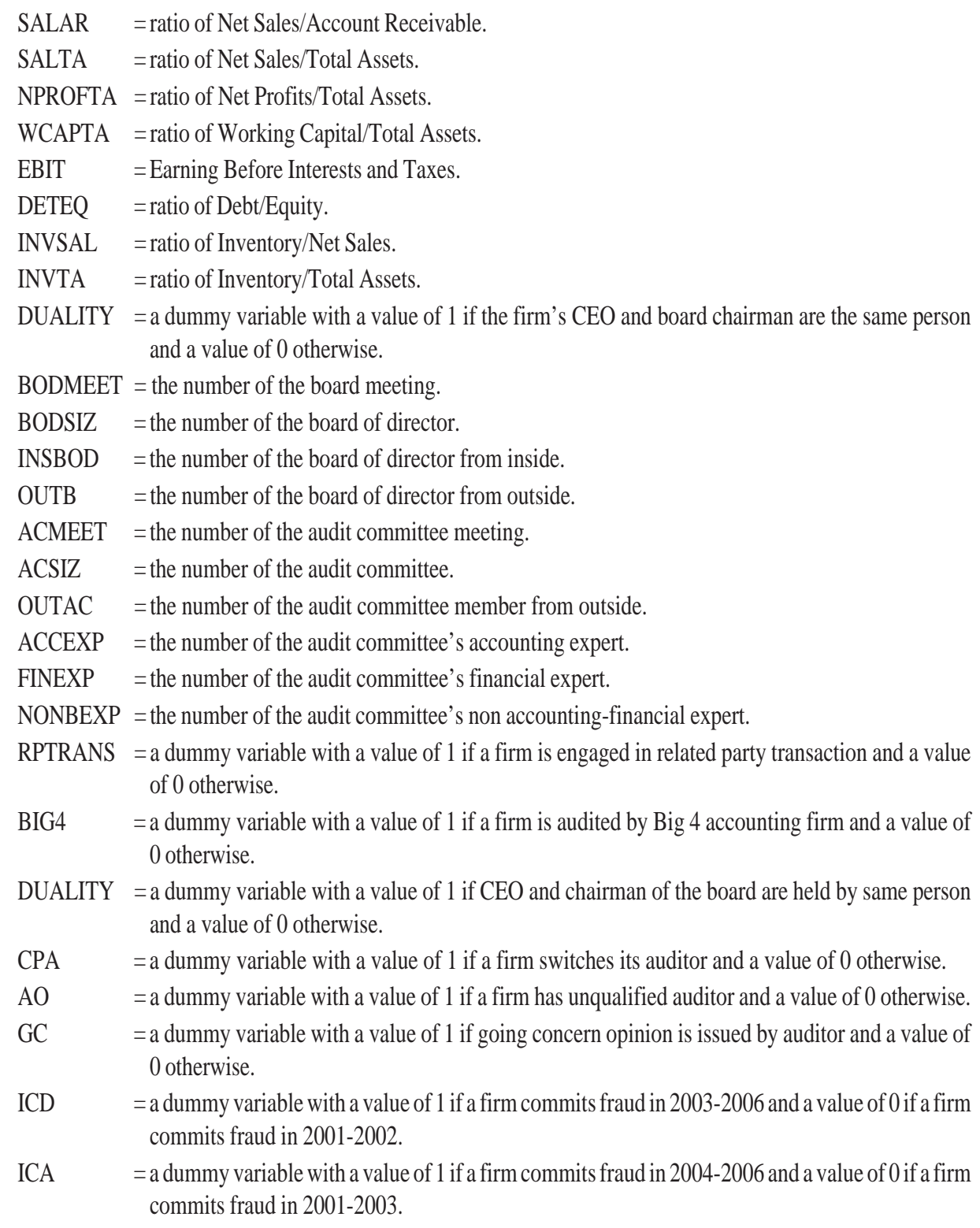


Gadjah Mada International Journal of Business, January -April 2009, Vol. 11, No. 1

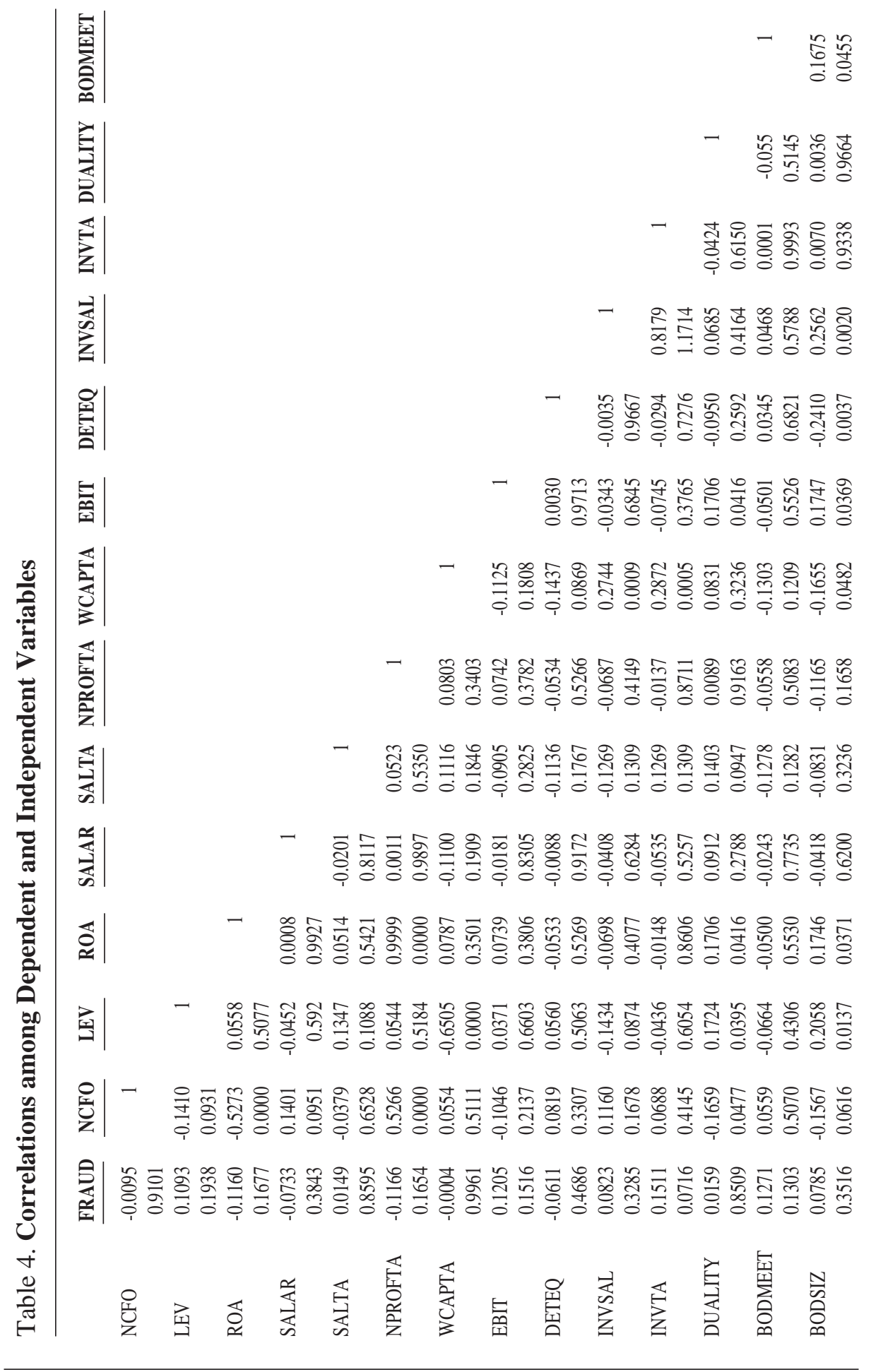




\section{Suyanto-Fraudulent Financial Statement}

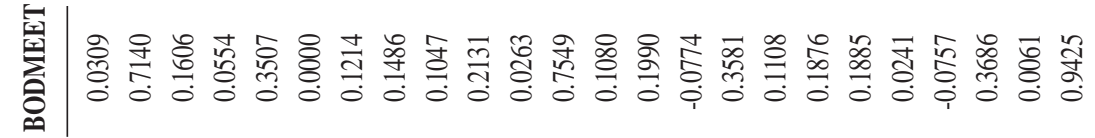

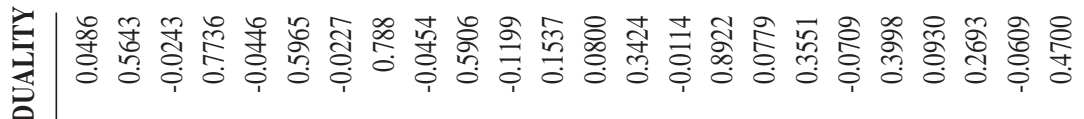

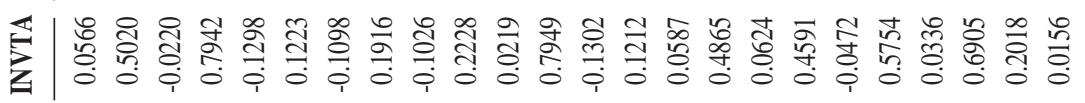

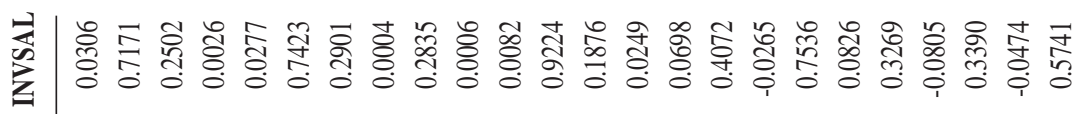

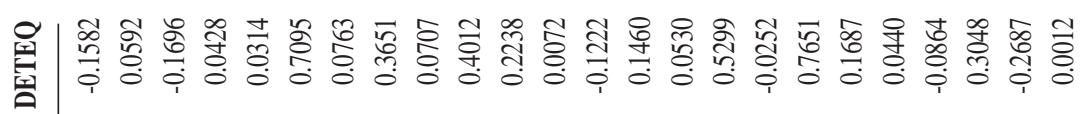

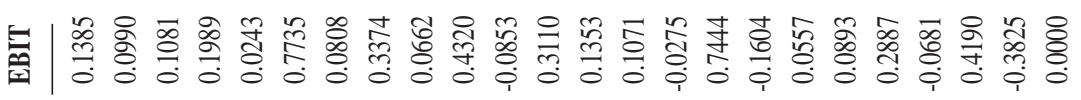

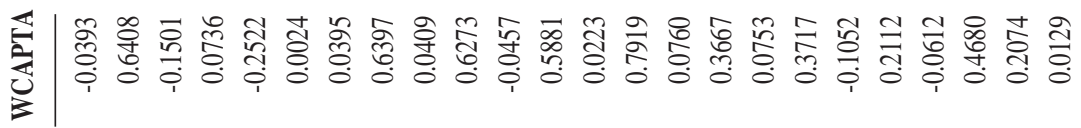

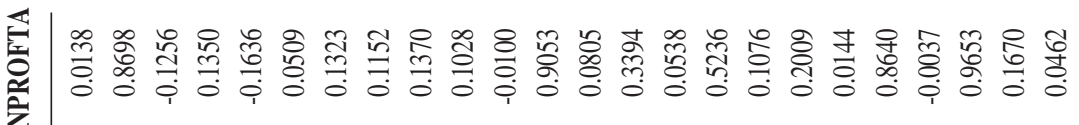

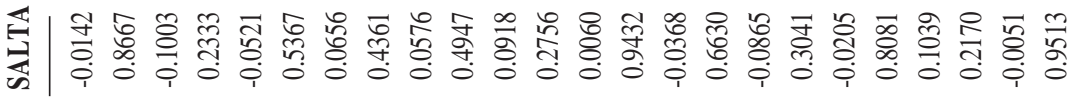

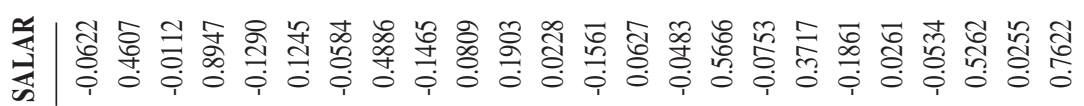

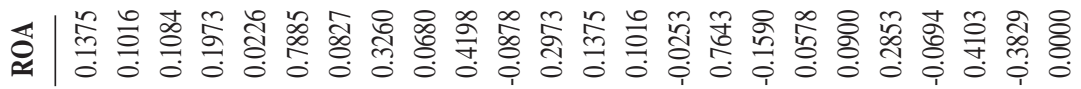

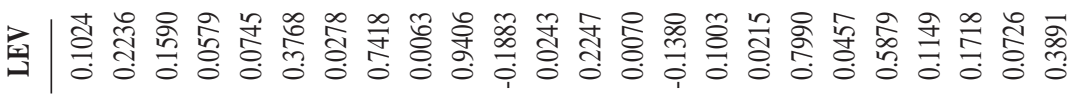

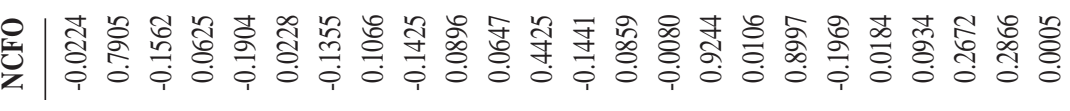
志

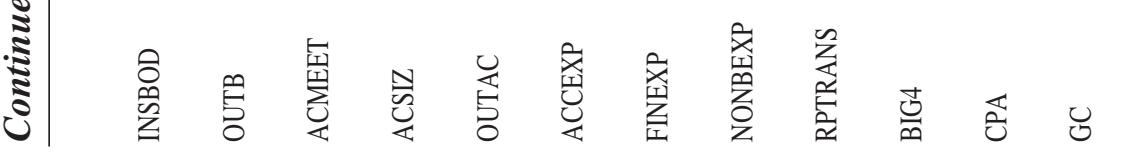


Gadjah Mada International Journal of Business, January -April 2009, Vol. 11, No. 1

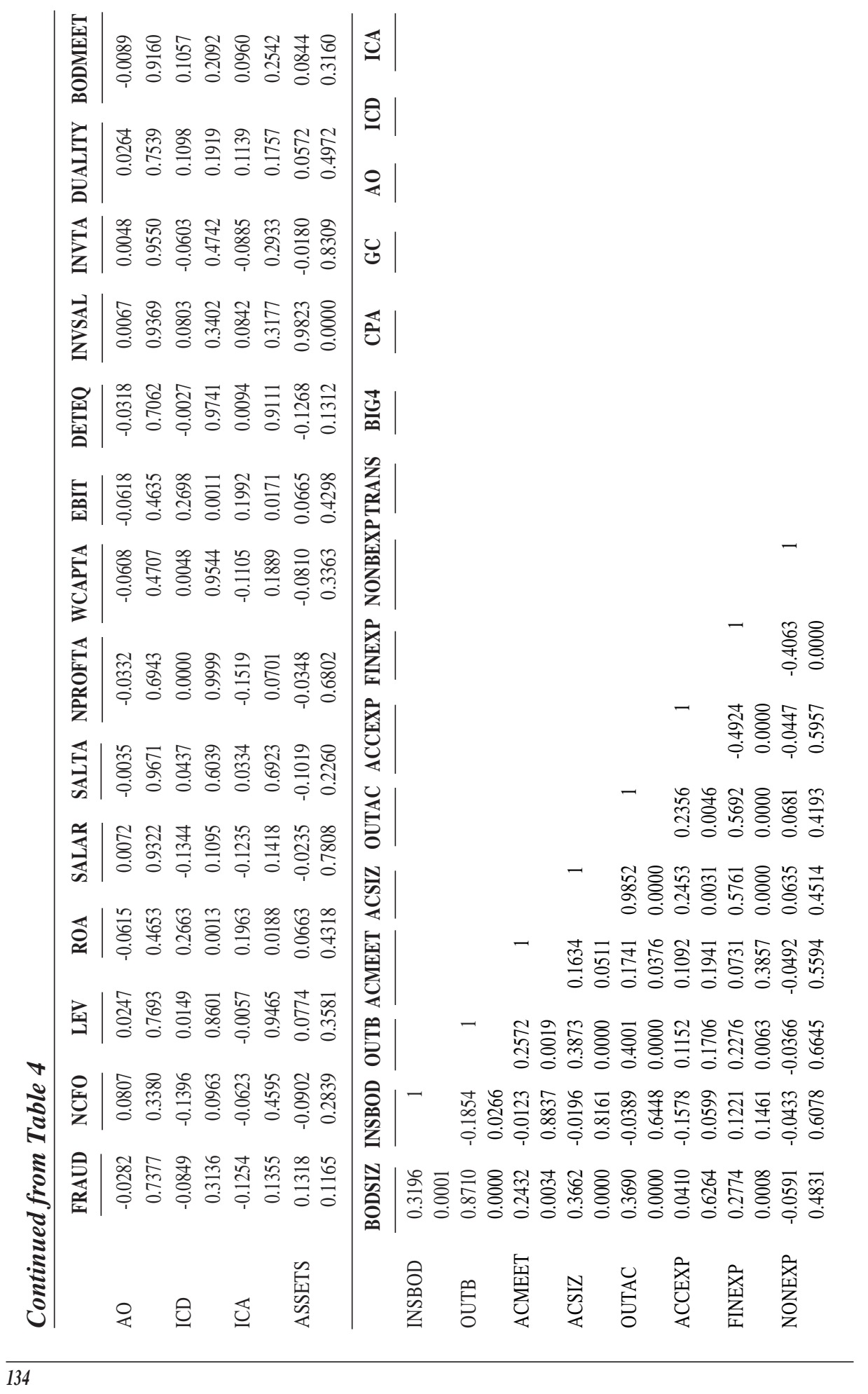


Suyanto-Fraudulent Financial Statement

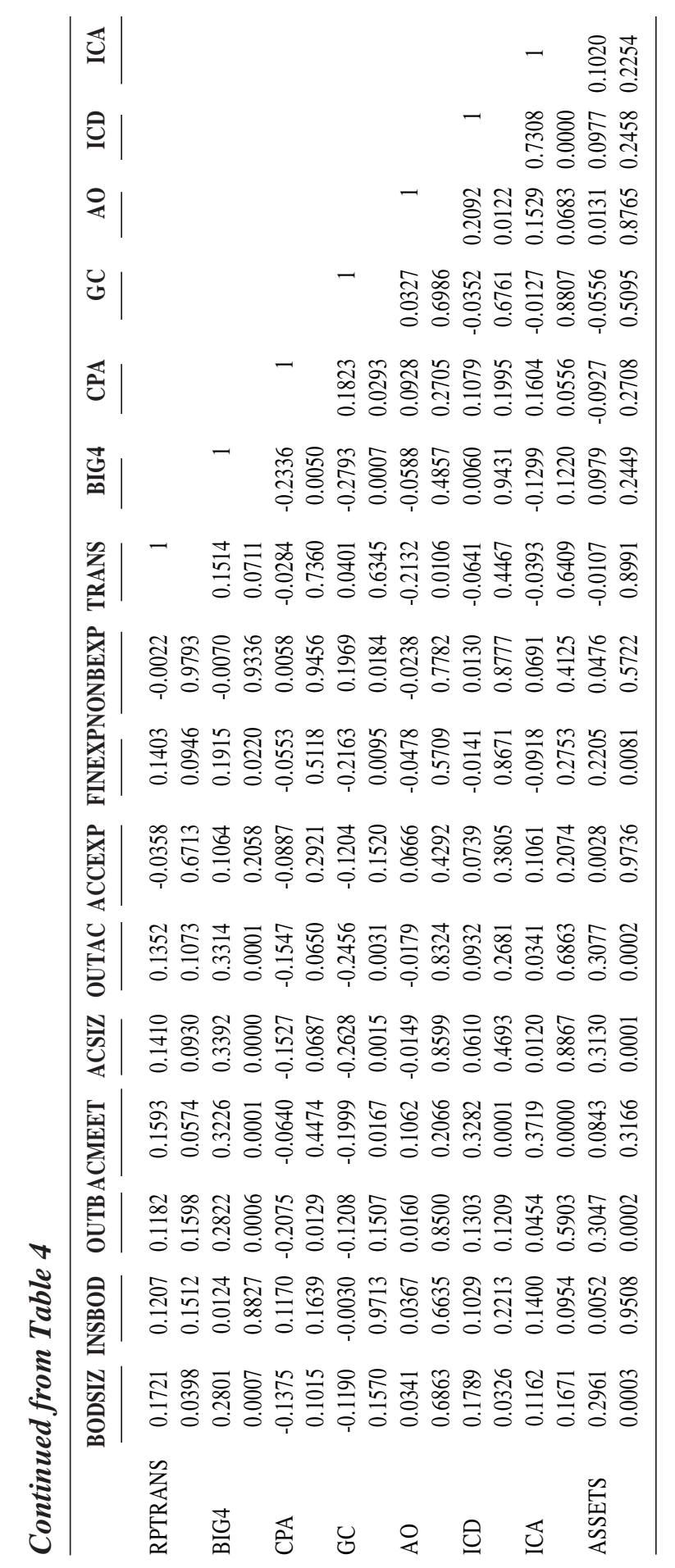


Gadjah Mada International Journal of Business, January -April 2009, Vol. 11, No. 1

Table 5. Initial Logistic Regression

\begin{tabular}{|c|c|c|c|c|}
\hline \multicolumn{5}{|c|}{$\begin{aligned} \text { FRAUD }= & \beta_{0}+\beta_{1} \text { NCFO }+\beta_{2} \text { LEV }+\beta_{3} \text { ROA }+\beta_{4} \text { SALTA }+\beta_{5} \text { SALTA }+ \\
& \beta_{6} \text { NPROFTA }+\beta_{7} \text { WCAPTA }+\beta_{8} \text { EBIT }+\beta_{9} \text { DETEQ }+\beta_{10} \text { INVSAL } \\
& +\beta_{11} \text { INVTA }+\beta_{12} \text { DUALITY }+\beta_{13} \text { BODMEET }+\beta_{14} \text { BODSIZ }+ \\
& \beta_{15} \text { ACMEET }+\beta_{16} \text { ACSIZ }+\beta_{17} \text { RPTRANS }+\beta_{18} \text { BIG } 4+\beta_{19} \text { CPA }+ \\
& \beta_{20} \text { GC }+\beta_{21} \text { AO }+\beta_{22} \text { ICD }+\beta_{23} \text { ICA }+\beta_{24} \text { LnASSETS }+\varepsilon\end{aligned}$} \\
\hline Variable $^{1}$ & B & S.E. & Wald & Sig. \\
\hline NCFO & -0.2200 & 0.6256 & 0.1237 & 0.7251 \\
\hline LEV & 0.6733 & 1.1490 & 0.3434 & 0.5579 \\
\hline ROA & -12.6484 & 46.5418 & 0.0739 & 0.7858 \\
\hline SALAR & -0.0008 & 0.0075 & 0.0104 & 0.9186 \\
\hline SALTA & 0.0312 & 0.1998 & 0.0244 & 0.8757 \\
\hline NPROFTA & 12.0467 & 46.6677 & 0.0666 & 0.7963 \\
\hline WCAPTA & -0.5142 & 1.4945 & 0.1184 & 0.7308 \\
\hline EBIT & 0.0013 & 0.0011 & 1.5914 & 0.2071 \\
\hline DETEQ & -0.0158 & 0.0192 & 0.6760 & 0.4110 \\
\hline INVSAL & -7.6260 & 4.6797 & 2.6556 & 0.1032 \\
\hline INVTA & 12.1185 & 5.0454 & 5.7692 & 0.0163 \\
\hline DUALITY & 0.1903 & 0.4647 & 0.1677 & 0.6821 \\
\hline BODMEET & 0.0326 & 0.0417 & 0.6115 & 0.4342 \\
\hline BODSIZ & -0.1666 & 0.1540 & 1.1698 & 0.2794 \\
\hline ACMEET & 0.0436 & 0.0427 & 1.0412 & 0.3075 \\
\hline ACSIZ & -0.1464 & 0.2908 & 0.2536 & 0.6146 \\
\hline RPTRANS & 2.2838 & 0.5631 & 16.4486 & 0.0000 \\
\hline BIG4 & -1.9761 & 0.9404 & 4.4161 & 0.0356 \\
\hline CPA & 0.2960 & 0.5055 & 0.3429 & 0.5582 \\
\hline GC & 0.3664 & 1.1443 & 0.1025 & 0.7488 \\
\hline $\mathrm{AO}$ & -2.2302 & 1.7079 & 1.7051 & 0.1916 \\
\hline ICD & 0.2037 & 0.7315 & 0.0775 & 0.7807 \\
\hline ICA & 0.6797 & 0.6711 & 1.0257 & 0.3112 \\
\hline LnAssets & -0.0422 & 0.2125 & 0.0394 & 0.8427 \\
\hline Intercept & -1.1057 & 1.9682 & 0.3156 & 0.5743 \\
\hline
\end{tabular}

Chi-Square for Model $=52.02 ; p$-value $=0.001 ;$ Pseudo $\mathrm{R}^{2}=0.414$

Hosmer \& L Test $=0.547$

${ }^{1}$ The variables are defined in Table 3. 


\section{Regression Results}

Table 6 statistically illustrates the logistic regression results for each element and the full regression.

The result for each fraud risk factor-Pressure, Opportunity, and Rationalization- will be described in the following sections as well as the full regression for the fraud triangle.

Model 1: Pressure. In model 1 of Table 6, NPROFTA is negatively and significantly associated with fraudulent financial statements, while LEV and SALTA are statistically insignificant. Pseudo ${ }^{2}$ is relatively low (0.071) and the p-value for the model is significant at 0.103 . The result indicates that a company with lower profitability tends to make errors in its financial statements or tries to make financial statements look better by cooking the books. This finding is in line with Person (1995) who states that lower profitability could encourage management to overstate revenues or understate expenses.

Model 2: Opportunity. Opportunity fraud risk factors in the model 2 of Table 6 produce figures that are statistically significant and have positive signs for INVTA and RPTRANS, and a negative sign for BIG4. Pseudo $\mathrm{R}^{2}$ (0.286) and p-value (0.000) also support the association between INVTA, RPTRANS, and BIG4, and the likelihood of committing frauds. The results are consistent with the second hypothesis, which states that the proxies are significant in explaining the link between Opportunity fraud risk factors and the tendency to commit financial statement frauds. Auditors should be careful in conducting inventory audits since it involves a subjective estimation and can easily be falsified. Related party transactions also give an opportunity to commit frauds since it may not reflect arm's-length bargaining between involved parties. These transactions can greatly influence revenue recognition if defects exist. Finally, audit quality -proxied by audit-firm size, brand name, and its ability to mitigate agency problemsmay also support the indication of fraud. Accounting firms -Big 4 usually provide a better audit quality, so they can reduce the opportunity to commit frauds.

Model 3: Rationalization. The third model tests the relationship between Rationalization fraud risk factors and the likelihood of financial statement frauds. Model 3 shows that none of the fraud risk factors for Rationalization is statistically significant. The result indicates that it is very difficult for auditors to observe fraud risk factors for Rationalization using public data, such as financial statements, analyst reports, performance reports, agenda, etc. Rationalization of fraud may only be appropriately revealed by interviewing perpetrators as Cressey (1953) did. This finding is also consistent with prior studies. Skousen and Wright (2006) fail to indentify and measure appropriate proxies. Brazel et al.(2007) intentionally do not try to make association between fraud risk factors for Rationalization and the likelihood of 
Gadjah Mada International Journal of Business, January -April 2009, Vol. 11, №. 1

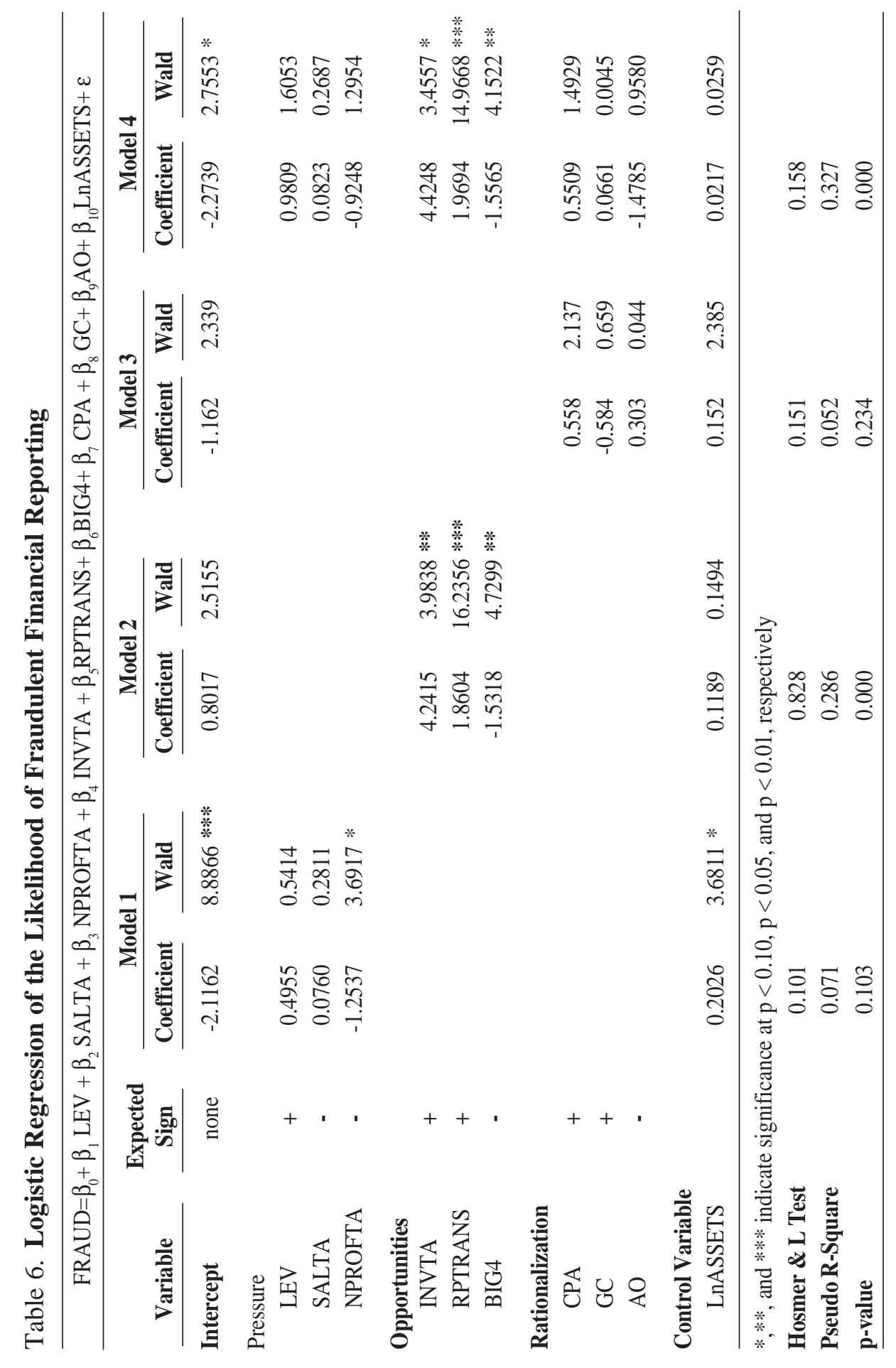


fraudulent financial statements. They argue that there is very limited or even no public data available to indentify and measure Rationalization for fraudulent behavior of management.

Model 4: Full Regression of Fraud Triangle. Model 4 of Table 6 displays the results of a full regression performed simultaneously using all proxies for Pressure, Opportunity, and Rationalization. The model finds that all three proxies for Opportunity (INVTA, RPTRANS, and BIG4) are consistently significant, while NPROFTA from Pressure fraud risk factors is no longer significant. Rationalization variables remain insignificant, and consistently support that Rationalization of fraud triangle seems to be the most difficult factor to be observed using public data.

\section{Additional Analysis}

Predictive Fraud Model and Robustness. In the next step, an additional analysis is presented in order to study further the possibility of fraud prediction model. For this purpose, this research uses the following model:

$$
\begin{aligned}
\text { FRAUD }= & \beta_{0}+\beta_{1} \text { NPROFTA }+ \\
& \beta_{2} \text { INVTA }+ \\
& \beta_{3} \text { RPTRANS }+\beta_{4} \text { BIG } 4+ \\
& \beta_{5} \text { LnASSETS }+\varepsilon
\end{aligned}
$$

where,

FRAUD = a dummy variable with a value of 1 if a firm is alleged to have committed a financial state-

$$
\begin{aligned}
& \begin{array}{l}
\text { ment fraud and a value } \\
\text { of } 0 \text { otherwise }
\end{array} \\
\text { NPROFTA = } & \text { ratio of Net Profits/To- } \\
& \text { tal Assets } \\
\text { INVTA }= & \text { ratio of Inventory/To- } \\
& \text { tal Assets } \\
\text { RPTRANS = } & \text { a dummy variable with } \\
& \text { a value of } 1 \text { if a firm is } \\
& \text { engaged in related party } \\
& \text { transactions and a value } \\
& \text { of } 0 \text { otherwise } \\
= & \text { a dummy variable with } \\
& \text { a value of } 1 \text { if a firm is } \\
& \text { audited by a Big } 4 \text { ac- } \\
& \text { counting firm and a } \\
& \text { value of } 0 \text { otherwise } \\
\text { BIG4 }= & \text { Ln Total Assets } \\
= & \text { Residual }
\end{aligned}
$$

These variables are employed because they are statistically significant at the individual level and in full regression scale, except for NPROFTA that is only significant at the individual level. The regression results are presented in Table 7. INVTA, RPTRANS and BIG4 are consistently significant to the likelihood of committing frauds, while NPROFTA is no longer significant. Table 7 also presents thegoodness-of-fit measures. The model's chi-square is 35.5 and statistically significant at $<0.01$. Pseudo $R^{2}$ is relatively higher $(0.299)$ and $p$-value is significant at $\mathrm{p}<0.01$. This model is seemingly appropriate for further analysis since both chi-square and pseudo $\mathrm{R}^{2}$ are significant.

Adhering to Skousen and Wright (2006), this study uses multiple discriminant analysis (MDA) and sensi- 
Gadjah Mada International Journal of Business, January -April 2009, Vol. 11, No. 1

Table 7. Fraud Prediction Model

\begin{tabular}{|c|c|c|c|c|}
\hline $\begin{aligned} \text { FRAUD }= & \beta_{0}+ \\
& \beta_{5} \operatorname{Ln} A\end{aligned}$ & $\begin{array}{l}\text { NPROFTA } \\
\text { ETS }+\varepsilon\end{array}$ & INVT & $3_{3} \mathrm{RPTR}$ & $\beta_{4}$ BIG4 + \\
\hline Chi-Square for $\mathrm{M}$ & lel $=35.5$ & & & \\
\hline$p$-value $\quad=$ & .000 & & & \\
\hline Pseudo $\mathrm{R}^{2}$ & $=0.299$ & & & \\
\hline Hosmer \& L Test & $=0.257$ & & & \\
\hline Variable & Coefficient & S.E. & Wald & $p$-value \\
\hline Intercept & -1.622 & 0.851 & 3.638 & $0.056 *$ \\
\hline NPROFTA & -0.947 & 0.740 & 1.638 & 0.201 \\
\hline INVTA & 4.605 & 2.230 & 4.265 & $0.039 * *$ \\
\hline RPTRANS & 1.753 & 0.468 & 14.056 & $0.000 * * *$ \\
\hline BIG4 & -1.587 & 0.736 & 4.646 & $0.031 * *$ \\
\hline LnAssets & 0.091 & 0.124 & 0.546 & 0.460 \\
\hline
\end{tabular}

$*$,**, and $* * *$ indicate significance at $\mathrm{p}<0.10, \mathrm{p}<0.05$, and $\mathrm{p}<0.01$, respectivel

tivity analysis to examine whether those fraud risk factors can be used to construct a fraud prediction model. One of the discriminant analysis methods is cross-validation method, which removes the first observation from the dataset and builds a discriminant model using the remaining observations (Jones 1987; Hair et al. 1995; and Kuruppu et al. 2003; Skousen and Wright 2006). Cross-validation method is very effective in providing an unbiased estimate of a model's mis-classification rate (Hair et al. 1995) and is particularly useful in studies with small sample size since the entire sample can be used to cross-validate the results (Kuruppu et al. 2003; Skousen and Wright 2006).
After performing the cross-validation method, the results as reported in Table 8 show that model accuracy is approximately 67.1 percent (or the overall misclassification rate of the model is 32.9 percent). Still in Table 8, the model correctly classifies nonfraudulent firms by 77 percent and correctly classifies fraudulent firms by 51 percent. Compared with Kaminski et al. (2004) who have a model success rate of 30 to 40 percent, this model has achieved a higher level of prediction and also has a lower misclassification for both fraudulent firms and non-fraudulent firms. Kaminski et al. (2004) correctly classify fraudulent firms by 2 to 42 percent and non-fraudulent firms by 84 to 90 percent. 


\begin{tabular}{|c|c|c|c|c|c|}
\hline & & & \multicolumn{2}{|c|}{$\begin{array}{l}\text { Predicted Group } \\
\text { Membership }\end{array}$} & \multirow[b]{2}{*}{ Total } \\
\hline & & & NFRAUD & FRAUD & \\
\hline \multirow{4}{*}{ Original } & Count & NFRAUD & 71 & 17 & 88 \\
\hline & & FRAUD & 24 & 31 & 55 \\
\hline & $\%$ & NFRAUD & $81 \%$ & $19 \%$ & $71.30 \%$ \\
\hline & & FRAUD & $44 \%$ & $56 \%$ & \\
\hline \multirow{4}{*}{ Cross-validated } & Count & NFRAUD & 68 & 20 & 88 \\
\hline & & FRAUD & 27 & 28 & 55 \\
\hline & $\%$ & NFRAUD & $77 \%$ & $23 \%$ & $67.10 \%$ \\
\hline & & FRAUD & $49 \%$ & $51 \%$ & \\
\hline
\end{tabular}

\section{Conclusion}

This research examines fraud risk factors and constructs a model to predict the likelihood of fraudulent financial statements based on the fraud triangle notion, which is adopted in SAS No.99 of AICPA (2002). From various setting of research designs, this study identifies some fraud risk factors that are significantly associated with the likelihood of committing frauds. Consistent with prior research, Pressurerepresented by net profit/total assets (NPROFTA)-and Opportunity-represented by inventory/total assets (INVTA), related party transaction (RPTRANS), and Big 4 of audit firms (BIG4)-are significantly related to the financial reporting frauds. Meanwhile, none of the Rationalization variables is found to be statistically relevant to the model. It seems that Rationalization attributes are more difficult to observe using public data than the other two elements of the fraud trianglePressure and Opportunity.

The second objective of this research is to construct a model to predict the likelihood of committing frauds using the identified fraud risk factors. Using the cross-validation method of discriminant analysis, it is indicated that the model can predict the tendency of fraudulent financial reporting with a relatively high success rate. Overall, the model correctly classifies firms by 67.1 percent; additionally, the model correctly classifies nonfraudulent firms by 77 percent and fraudulent firms by 51 percent.

Nevertheless, there are some limitations of this research. First, fraudulent firm data are very limited. Only information on fraudulent firms subject to SEC enforcement actions is publicly available. Second, the predic- 
Gadjah Mada International Journal of Business, January -April 2009, Vol. 11, No. 1

tive fraud model may misclassify non-

fraudulent firms, which have in fact committed fraud, but have not been subject to the SEC enforcement.

\section{Reference}

AICPA. 2007. AU section 316: Consideration of fraud in a financial statement audit. AICPA.

Agrawal, A., and S. Chadha. 2005. Corporate governance and accounting scandals. Journal of Law and Economics 48: 371-406.

Albrecht, W. S., C. C. Albrecht, and C. O. Albrecht. 2006. Fraud Examination. Thomson South-Western.

Beasley, M. S. 1996. An empirical analysis of the relation between the board of director composition and financial statement fraud. The Accounting Review 71 (4):443-465.

Beasley, M. S., J. V. Carcello, and D. R. Hermanson. 1999. Fraudulent financial reporting: 1987-1997 an analysis of U.S. public companies. In Research Report: Committee of Sponsoring Organizations of the Treadway Commission 68.

Bell, T. B., and J. V. Carcello. 2000. A decision aid for assessing the likelihood of fraudulent financial reporting. Auditing: A Journal of Practice 19 (1):169-184.

Beneish, M. D. 1997. Detecting GAAP Violation: Implications for Assessing Earnings Management among Firms with Extreme Financial Performance. Journal of Accounting and Public Policy 16:271-309.

Brazel, J. F., K. Jones, and M. F. Zimbelman. 2007. Using nonfinancial measures to assess fraud risk. In Working Paper. North Carolina State University, George Mason University, and Brigham Young University 45.

Carmichael, D. R. 1999. Hocus-pocus accounting. Journal of Accountancy (October): 5965.

Chen, K. Y., and R. J. Elder. 2007. Fraud risk factors and the likelihood of fraudulent financial reporting: Evidence from statement on Auditing Standards No. 43 in Taiwan. In Working Paper. National Taiwan University and Syracuse University, 36.

Cressey, D. R. 1953. Other people's Money: A Study in the Social Psychology of Embezzlement. Glencoe, Illinois: The Free Press

DeFond, M. L. 1992. The association between changes in client firm agency costs and auditor switching. Auditing: A Journal of Practice 11 (1): 16-31.

Ellingsen, J. E., K. Pany, and P. Fagan. 1989. SAS no. 59: How to evaluate going concern. Journal of Accountancy (January): 24-31.

Fama, E. F., and M. C. Jensen. 1983. Separation of ownership and control. Journal of Law and Economics 26 (2): 301-325.

Farber, D. B. 2005. Restoring trust after fraud: Does corporate governance matter? The Accounting Review 80 (2): 539-561.

Francis, J. R. 1999. Accounting accruals and auditor reporting conservatism. Contemporary Accounting Research 16 (1): 135-165. 


\section{Suyanto-Fraudulent Financial Statement}

Ge, W., and S. McVay. 2005. The disclosure of material weaknesses in internal control after the Sarbanes-Oxley Act. Accounting Horizons 19 (3): 137-158.

Hopwood, W., J. McKeown, and J. Mutchler. 1989. A test of the incremental explanatory power of opinions qualified for consistency and uncertainty. The Accounting Review 64 (1): 28-48.

Johnson, W. B. and Lys T. 1990. The market for audit services: Evidence from voluntary auditor changes. Journal of Accounting and Economics 12 (January).

Kaminski, K. A., T. S. Wetzel, and L. Guan. 2004. Can financial ratio detect fraudulent financial reporting? Managerial Auditing Journal 19 (1): 15-28.

Kirkos, E., C. Spathis, and Y. Manolopoulos. 2007. Data mining techniques for the detection of fraudulent financial statements. Expert Systems with Applications 32: 995-1003.

Klein, A. 2002. Audit committee, board of director characteristics, and earnings management. Journal of Accounting and Economics 33: 375-400.

Kreutzfeldt, R., and. Wallace, W. 1986. Error characteristics in audit populations: Their profile and relationship to environment factors. Auditing: A Journal of Practice and Theory (Fall): 20-43

Krishnan, J., and J. Krishnan. 1997. Litigation risk and auditor resignations. The Accounting Review 70 (4): 539-560.

Kuruppu, N., F. Laswad, and P. Oyelere. 2003. The efficacy of liquidation and

bankruptcy models for assessing going concern. Managerial Auditing Journal 18 (6/7): 577-590.

Loebbecke, J. K., M. M. Eining, and J. J. Willingham. 1989. Auditors’ experience with material irregularities: Frequency, nature, and detectability. Auditing: A Journal of Practice 9 (1):1-28.

Palepu, K. G. 1986. Predicting takeover targets: A methodological and empirical analysis. Journal of Accounting and Economics 8: 3-35.

Palmrose, Z.-V. 1988. 1987 Competitive manuscript co-winner: An analysis of auditor litigation and audit service quality. The Accounting Review 63 (1): 55-73.

Patterson, E. R., and J. R. Smith. 2007. The effect of Sarbanes-Oxley on auditing and internal control strength. The Accounting Review 82 (2): 427-455.

Persons, O. S. 1995. Using financial statement data to identify factors associated with fraudulent financial reporting. Journal of Applied Business Research 11 (3): 38.

Ramos, M. 2003. Auditors' responsibility for fraud detection. Journal of Accountancy January: 28-36.

Rezaee, Z. 2005. Causes, consequences, and deterrence of financial statement fraud. Critical Perspectives on Accounting 16: 277-298.

Schwartz, K. B., and K. Menon. 1985. Auditor switches by failing firms. The Accounting Review 60 (2): 248-261. 
Gadjah Mada International Journal of Business, January -April 2009, Vol. 11, No. 1

Skousen, C. J., and C. J. Wright. 2006. Contemporaneous risk factors and the prediction of financial statement fraud. In Working Paper. University of Texas at Arlington and Oklahoma State University, 41.

St. Pierre, K., and J. Anderson. 1984. An analysis of the factors associated with lawsuits against public accountants. The Accounting Review (April): 242-263.

Stice, J. D. 1991. Using financial and market information to identify pre-engagement factors associated with lawsuits against auditors. The Accounting Review 66 (3): 516533.

Uzun, H., S. H. Szewczyk, and R. Varma. 2003. Board composition and corporate fraud. Financial Analysts Journal (May/June): 33-43.

Vermeer, T. E. 2003. The impact of SAS No. 82 on an auditor's tolerance of earnings management. Journal of Forensic Accounting 14: 21-34.

Young, B. 2005. Related-party transactions: Why they matter and what is disclosed. The Corporate Governance Advisor 13 (4): 1-7. 